\title{
Spatial and temporal variations in mantle source and subduction contributions in the southern Cascade arc: Insights from mafic magma geochemistry
}

\author{
E.R. JOHNSON"*, J.S. SHAFFER', M.A. COLE', F.C. \\ RAMOS', A.T. CALVERT ${ }^{2}$ \\ 'Department of Geological Sciences, New Mexico State \\ University, Las Cruces, NM 88003 (*correspondence: \\ erj@nmsu.edu) \\ 2 USGS, 45 Middlefield Road, Menlo Park, CA 94025
}

Basaltic magmas erupted in the Cascade arc of the northwestern U.S. reflect a range of origins, from subductionderived to decompression melts. Here we use basalt geochemistry (including whole-rock and melt inclusion major and trace elements, volatiles, $\mathrm{Sr}-\mathrm{Nd}-\mathrm{Hf}-\mathrm{Pb}$ isotopes) and ${ }^{40} \mathrm{Ar} /{ }^{30} \mathrm{Ar}$ geochronology coupled with geochemistry of seafloor sediment from the subducting Gorda Plate to investigate spatial and temporal variations in mantle source and subduction contributions in the southern Cascades. Magma compositions include relatively primitive ( $\leq 9 \mathrm{wt} \%$ $\mathrm{MgO}$ ) calc-alkaline (CAB), low-K tholeiite (LKT) and intraplate-type (IPB) basalts. Olivine-hosted melt inclusions from the three magma types have low to moderate $\mathrm{H}_{2} \mathrm{O}$ contents ( $\leq 3 \mathrm{wt} \%$ ); in general, $\mathrm{H}_{2} \mathrm{O}, \mathrm{S}$ and $\mathrm{Cl}$ concentrations are higher in $\mathrm{CAB}$ and LKT magmas, suggesting a greater subduction contribution compared to the IPBs.

To assess mantle and subduction contributions to the magmas, we used PRIMACALC2 [1] and Arc Basalt Simulator 5 [2] to model primary melt compositions and the contributions of subducted sediment and/or oceanic crust ("subduction component") to the magmas. Similar to previous studies, we find that the sub-arc mantle becomes more enriched (e.g., higher $\mathrm{Nb} / \mathrm{Zr}$ ) northward along the arc, and that enriched magmas have minimal-no subduction input. In southern Oregon, our results suggest $\mathrm{CAB}$ magmas are derived from small amounts $(<10 \%)$ of sediment-rich subduction component added to depleted mantle, whereas LKT magmas have minimal $(\sim 4 \%)$ subduction contribution. Additionally, our results indicate that the composition of the subduction component has changed over time, from dominantly oceanic-crust-derived to more sediment-rich over the past $\sim 3 \mathrm{Ma}$.

[1] Kimura and Ariskin (2014), Geochem. Geophys. Geosyst. 15, 1494-1514. [2] Kimura (2017) Geosphere 13, 992-1025. 